\title{
Bir Boyutlu Dinamik Analiz ve Mikrotremor Ölçüm Sonuçlarının Karşılaştırılması
}

\author{
Ozan SUBAŞI ${ }^{1}$ \\ M. Emre HAŞAL ${ }^{2}$ \\ Bilal ÖZASLAN ${ }^{3}$ \\ Recep IYYISAN ${ }^{4}$ \\ Hiroaki YAMANAKA ${ }^{5}$ \\ Kosuke CHIMOTO ${ }^{6}$
}

\section{ÖZ}

Depremler sırasında zemin tabakalarında oluşan deformasyon seviyeleri, yapı-zemin etkileşiminde önemli rol oynamaktadır. Kuvvetli yer hareketi kayıtları kullanılarak yapılan bir boyutlu (1D) dinamik analizlerle yüzeye yakın zemin tabakaları için hesaplanan kayma şekil değiştirmeleri; küçük genlikli titreşimler-mikrotremor verisi analiz sonuçlarının, tasarım yer hareketine ait en büyük yatay ivme değeriyle birlikte değerlendirilmesiyle de tahmin edilebilmektedir. Bu çalışmada, Kuzey Anadolu Fay Hattına yakın bir bölgede zemin tabakalarının deprem hareketi karşısındaki davranışı; hem 14 farklı anakaya ivme kaydı kullanılarak yapılan 1D eşdeğer lineer dinamik analizlerle hem de mikrotremor ölçümlerinin analizi yardımıyla elde edilmiştir. Verilerin değerlendirilmesi sonucunda, kuvvetli yer hareketi sırasında yüzeye yakın zemin tabakalarında oluşacak kayma birim şekil değiştirmesinin belirlenebilmesi amacıyla; elastik ve elasto-plastik deformasyon seviyelerini kapsayan bir bağıntı önerilmiştir.

Anahtar Kelimeler: 1D dinamik analiz, mikrotremor, kayma birim şekil değiştirmesi.

Not: Bu yazı

- Yayın Kurulu'na 28 Şubat 2018 günü ulaşmıştır. 01 Şubat 2019 günü yayımlanmak üzere kabul edilmiştir.

- 30 Kasım 2019 gününe kadar tartışmaya açıktır.

- https://dx.doi.org/10.18400/tekderg.399710

1 Türk-Alman Üniversitesi, İnşaat Mühendisliği Bölümü, İstanbul - ozansb@gmail.com https://orcid.org/ 0000-0001-6931-0590

2 Bursa Büyükşehir Belediyesi, Fen İşleri Dairesi Bşk., Bursa - murat.hasal@bursa.bel.tr https://orcid.org/0000-0003-3466-7885

3 İstanbul Teknik Üniversitesi, İnşaat Mühendisliği Bölümü, İstanbul - ozaslanb@itu.edu.tr https://orcid.org/0000-0001-7951-1759

4 İstanbul Teknik Üniversitesi, İnşaat Mühendisliği Bölümü, İstanbul - iyisan@itu.edu.tr https://orcid.org/0000-0002-0887-9983

5 Tokyo Institute of Technology, Yokohama, Japonya - yamanaka@depe.titech.ac.jp https://orcid.org/0000-0002-5937-4707

6 Tokyo Institute of Technology, Yokohama, Japonya - chimoto.k.aa@m.titech.ac.jp https://orcid.org/0000-0003-0117-5868 


\section{ABSTRACT \\ Comparison of One Dimensional Dynamic Analysis and Microtremor Measurement Results}

The deformation level of the surface soil layer due to strong ground motion has a considerable effect in soil-structure interaction problems. The shear strain values of the near surface soil deposits which are calculated by one dimensional (1D) seismic site response analyses can also be estimated by incorporating the results obtained from Horizontal to Vertical Spectral Ratio (HVSR) analysis of microtremor data and peak horizontal acceleration value of design ground motion. In this study, the seismic behaviors of soil layers at a site located in the vicinity of North Anatolian Fault were estimated by using the results of both $1 \mathrm{D}$ equivalent linear seismic site response analyses for 14 different seismic excitation records and HVSR analyses of ground ambient noise-microtremor measurement data. A correlation is proposed for elastic and elasto-plastic deformation levels of surface soil layers in order to estimate the value of shear strain due to strong ground motion.

Keywords: 1D seismic site response analysis, microtremor, shear strain.

\section{GíRiş}

Depremler sırasında oluşan kuvvetli yer hareketinin mühendislik yapılarında meydana getirdiği hasarı etkileyen faktörler, deprem kaynak özellikleri, yerel zemin koşulları ve üstyapı özellikleridir. Yerel zemin koşulları ve deprem kaynak özellikleri, zemin yüzeyinde oluşan kuvvetli yer hareketinin özelliklerini, bu özelliklerin yerel değişimi ise yapısal hasar dağılımını etkilemektedir. Bu nedenle depreme dayanıklı yapı tasarımında; deprem kaynak özellikleri, yerel zemin koşulları ve yapıların mühendislik özellikleri birlikte dikkate alınmalıdır. Deprem hareketi nedeniyle yüzeye yakın zemin tabakalarında meydana gelen kayma deformasyonlarının seviyesi, yapılarda oluşan hasar dağılımının sahadaki değişiminde etkili olmaktadır. Kuvvetli yer hareketi sırasında yüzeye yakın zemin tabakalarında oluşacak kayma birim şekil değiştirmesinin sismik anakayadaki tasarım hareketinin şiddetine bağlı olarak doğru biçimde öngörülebilmesi, zemin yapılarında ve üstyapılarda deprem sırasında oluşacak olumsuz etkileri en aza indirecek mühendislik çözümlerinin geliştirilmesinde önemli katkı sağlayacaktır. Tasarım yer hareketi karşısında yüzeye yakın zemin tabakalarında meydana gelecek kayma deformasyonu değerlerinin yaklaşık olarak belirlenebilmesi amacıyla, farklı malzeme modellerinin ve hesap yöntemlerinin kullanıldığı bir, iki ve üç boyutlu sayısal dinamik analiz yöntemleri geliştirilmiştir. Bir boyutlu analiz yöntemlerinde, zemin kesitindeki tabakaların dinamik özellikleri, kalınlıkları, sismik anakaya derinliği yeterli olmakta, iki ve üç boyutlu analiz yöntemlerinde ise tabakaların iki veya üç boyutlu geometrisi ve sınır şartlarına da ihtiyaç duyulmaktadır. Ayrıca analizlerde kullanılan sismik anakaya hareketinin karakteristiklerinin depremin kaynak özelliklerini doğru biçimde yansıtması gerekmektedir. Kuvvetli yer hareketi sırasında yüzeye yakın zemin tabakalarında meydana gelecek kayma şekil değiştirmesi değerlerinin; basit ve uygulama kolaylığına sahip yöntemlerle yaklaşık olarak elde edilmesi, deprem hareketinin yüzeyde oluşturacağı etkilerin belirlenmesinde önemli rol oynayacaktır [1]. Bununla birlikte yüzeye yakın zemin tabakalarında kuvvetli yer hareketine bağlı oluşacak kayma deformasyonlarının belirlenmesinde; mikrotremor ölçümleri de alternatif bir tahmin yöntemi olarak değerlendirilmektedir. Mikrotremor ölçümleri; 
uygulama kolaylığı, düşük maliyeti, veri kayıt ve analiz sürelerinin görece kısalı̆̆ı sebebiyle tercih edilmektedir. Mikron mertebesindeki $\left(10^{-2} \sim 10^{-3} \mathrm{~mm}\right)$ çok küçük genlikli yer hareketinden oluşan mikrotremorlar, zemin tabakaları arasındaki rijitlik farklılığının meydana getirdiği empedans (özgül direnç) oranına bağlı büyütmeler dışında; tabakalara ait Poisson Oranı, titreşim kaynaklarının karakteri, derinliği ve uzaklığı vb. parametrelerden büyük oranda etkilenmektedir. Zemin yüzeyinde alınan üç bileşenli tekil mikrotremor kayıtlarının H/V (yatay/düşey) Spektral Oran yöntemiyle analizi yapılarak, sahaya ait hakim periyot ve spektral büyütme değerleri elde edilebilmektedir [2]. Kuvvetli yer hareketi özellikleri ile arasında kuramsal farklılık olmasına rağmen, mikrotremor ve zayıf yer hareketi ölçümleri; geoteknik deprem mühendisliğinde kuvvetli yer hareketi karşısında zemin tabakalarının gösterdiği dinamik davranışı tahmin etmekte, yaygın olarak kullanılmaktadır. Literatürde, mikrotremor ölçümlerinin $\mathrm{H} / \mathrm{V}$ Spektral Oran yöntemiyle analizi esasına dayanan ve mikrotremor kayıtlarından elde edilen büyütme değerleriyle kuvvetli yer hareketinin analizi veya zemin tabakalarının bir boyutlu dinamik analizi sonucunda hesaplanan büyütme değerlerini karşılaştıran birçok çalışma mevcuttur [3, 4].

$\mathrm{Bu}$ çalı̧̧ada küçük genlikli titreşimler olarak bilinen mikrotremor ölçümlerinin Nakamura (2008) tarafından önerilen yöntemle elde edilen kayma şekil değiştirmeleri, sismik anakaya mostrasında kaydedilmiş farklı ivme-zaman geçmişleri kullanılarak yapılan bir boyutlu-1D dinamik analizlerden hesaplanan değerlerle karşılaştırılmıştır. İnceleme bölgesinde daha önce zemin etüdü sondajlarının yapıldığı noktalarda 6 adet eş zamanlı çoklu (Array) ve 15 adet tekil mikrotremor kayıtları alınmıştır. Eş zamanlı mikrotremor ölçüm kayıtları SPAC (Uzamsal Özilişki) yöntemi ile analiz edilerek kayma dalgası hızının derinlikle değişimi belirlenmiştir. Ayrıca, inceleme sahalarında daha önce yapılan zemin etüdü sondajı verileri, Standart Penetrasyon Deneyi darbe sayıları (SPT-N) ve laboratuvar deneyi sonuçları derlenmiş; bu veriler, eş zamanlı mikrotremor ölçümlerinden elde edilen kayma dalgası hızının derinlikle değişimi ile birlikte değerlendirilerek ölçüm yapılan sahalarda zemin modelleri oluşturulmuştur. Bu zemin modelleri üzerinde en büyük mutlak ivme değerleri ( $\left.\mathrm{a}_{\text {maks_kaya }}\right) 0.3 \mathrm{~g}, 0.4 \mathrm{~g}$ ve $0.5 \mathrm{~g}$ olan 14 farklı anakaya mostrası ivme zaman geçmişi kullanılarak, bir boyutlu (1D) eşdeğer lineer dinamik analizler yapılmış ve yüzeye yakın zemin tabakaları için kayma şekil değiştirmeleri elde edilmiştir. Yapılan tekil mikrotremor ölçümleri; H/V Spektral Oran yöntemine göre analiz edilmiş, zemin büyütmesi ile hakim periyot değerleri ve bunlara bağlı Nakamura İndisi $\left(K_{g}\right)$ değerleri hesaplanmıştır. Nakamura İndisi değerlerinin sahadaki sismik anakaya için öngörülen en büyük mutlak ivme değerleriyle birlikte ele alınması sonucunda yüzeye yakın zemin tabakaları için efektif kayma şekil değiştirmesi değerleri $\left(\gamma_{e}\right)$ hesaplanmıştır [4]. Tekil mikrotremor ölçümlerinden elde edilen efektif kayma şekil değiştirmesi değerleri 1D analizlerden bulunanlarla $\left(\gamma_{I D}\right)$ karşılaştırılmış ve aralarındaki ilişki araştırılmıştır.

\section{2. ÇALIŞMA ALANI VE YEREL ZEMIN KOŞULLARI}

İnceleme bölgesi Marmara Denizi'nin güneydoğusunda, Gemlik Fayı yakınında yer almakta ve deniz kıyısından yaklaşı $500 \mathrm{~m}$ içeriye uzanan, $2 \mathrm{~km}$ uzunluğunda sahil şeridi içinde bulunmaktadır. Söz konusu bölgede yer alan düzlükler, kıyı çökelleri ve alüvyonlar ile kaplı olup kıyı şeridine paralel bir şekilde uzanmaktadır. Sahil şeridinin güneyinde yer alan alüvyon tabakası doğu-batı doğrultusunda uzanmaktadır. Neojen döneme ait konglomera, kumtaşı, kiltaşı, marn ve kireçtaşı ardalanması, alüvyon ve sahil çökelinin güneyindeki 
tepelik alanlarda gözlenmektedir. İnceleme bölgesinin güneydoğusunda Eosen döneme ait andezitlerden oluşan volkanik birimler yer almaktadır. Triyas yaşlı kaya mostraları bölgenin doğusunda gözlenmektedir. Kuvaterner yaşlı alüvyonlar, bataklık çökelleri ve kıyı çökelleri ile Neojen yaşlı konglomera, kumtaşı, kiltaşı, kireçtaşı ve marndan oluşan çökeller bölgenin esas jeolojisini oluşturmaktadır [5]. Bölgedeki alüvyonlar genellikle çakıllı kumlu kil ve siltli kil şeklinde ince taneli çökellerden, kıyı çökelleri ise genellikle çakıllı siltli kum zeminden oluşmaktadır. Marmara Bölgesi sınırlarında bulunan çalışma sahasının yeri ve uydu görünümü Şekil 1'de verilmiştir.

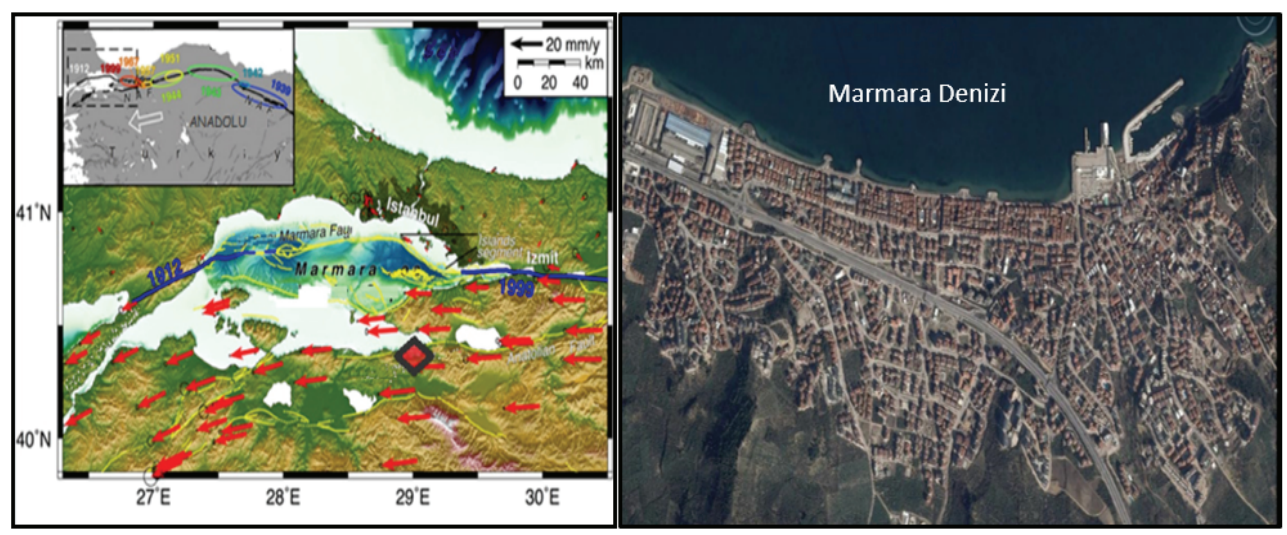

Şekil 1 - Çalışma Sahasının Yeri ve Uydu Görünümü

İnceleme bölgesinde yapılan ve derinlikleri yaklaşık 15 35 m olan sondaj çalışmalarının sonucunda, zemin kesitinin yer yer çakıl içeriği yüksek kumlu kil-killi siltli kum tabakalarından meydana gelmiş alüvyondan, siltli kum-siltli çakıl içerikli deniz çökelinden ve ayrışmış Neojen çökellerinden oluştuğu belirlenmiştir. İnceleme sahasının büyük bir bölümünde zemin yüzeyinden itibaren $30 \mathrm{~m}$ derinlikte, orta katı-katı siltli kil ve yer yer çakıl bantı içerikli orta sıkı siltli kum tabakalarının ardalanmasından oluşan alüvyon yer almaktadır (Şekil 2). İnceleme sahasının güneyinde ve batısında, zemin yüzeyinde çok katı-katı kumlu kil tabakası ve altında ise Neojen yaşlı ayrışmış kumtaş1-kiltaşı-silttaşı-marn ardalanması yer almaktadır. Sahanın doğusunda ise zemin yüzeyinden itibaren ilk $20 \mathrm{~m}$ derinlikte; yer yer orta sıkı siltli kum tabakaları içeren orta katı-katı kumlu kilden meydana gelmiş alüvyon mevcut olup, altında ise ayrışmış andezit, şist ve meta-kireçtaşı birimleri mevcuttur [6].

\section{ARAZİ DENEYLERİ VE DEĞERLENDİRILMESİ}

Bu çalışmada; inceleme sahasında daha önce yapılmış olan derinlikleri $15 \mathrm{~m}$ ile $35 \mathrm{~m}$ arasında değişen 22 adet sondaj noktasının yakınlarında 15 adet tekil ve 6 adet çoklu eş zamanlı olmak üzere toplamda 21 adet mikrotremor ölçümleri gerçekleştirilmiştir. Bölgede önceden yapılan sondajların ve bu çalışma kapsamında yapılan mikrotremor ölçüm noktalarının yerleşim planı Şekil 2'de gösterilmiştir. Sondajlar sırasında uygulanmış penetrasyon deneylerinden 
elde edilen SPT-N sayıları, alınan numuneler üzerinde uygulanan laboratuvar deney sonuçları, eş zamanlı mikrotremor ölçümlerinin SPAC analizinden elde edilen kayma dalgası hızının derinlikle değişimi birlikte değerlendirilerek her sondaj noktasında bir boyutlu dinamik analizler için serbest zemin modelleri oluşturulmuştur. Aynı noktalarda yapılan tekil mikrotremor ölçüm sonuçlarından H/V Spektral Oranı yöntemi kullanılarak, zemin hakim periyodu $\left(T_{0}\right)$ ile zemin büyütmesi $\left(A_{g}\right)$ değerleri elde edilmiş ve bunlara bağlı olarak hasar görebilirlik indisi değerleri hesaplanmıştır. Tekil mikrotremor kayıtlarının analiz sonuçları, sismik anakaya için öngörülen yer hareketinin en büyük ivme değeriyle birlikte ele alınarak kayma birim şekil değiştirmeleri belirlenmiş̧ir.

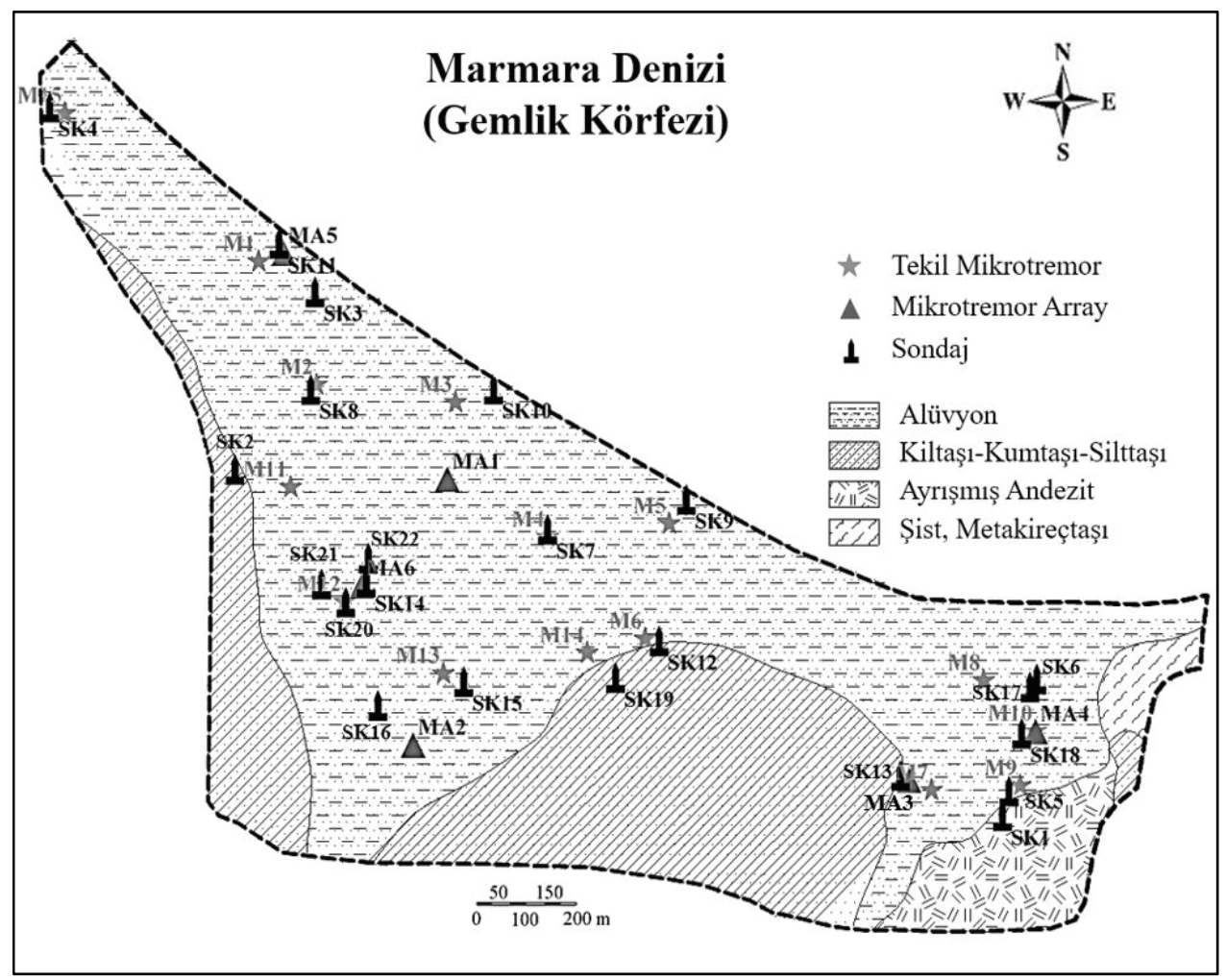

Şekil 2 - İnceleme Sahası Genel Zemin Koşulları, Sondaj ve Mikrotremor Ölçüm Noktaları Yerleşim Planı

\subsection{Sondajlar ve Penetrasyon Deneyleri}

İnceleme bölgesinde geoteknik incelemeler kapsamında zemin kesitinde yer alan tabakaların cinslerini, kalınlıklarını ve özelliklerini belirlemek amacıyla önceden yapılmış 22 adet zemin araştırma sondajına ait veriler derlenmiş̧ir. Çalışma sahasında yapılmış sondaj kuyularına ait 
örnek kesitler ile bu kuyular içinde yapılmış arazi penetrasyon deneylerinden elde edilen SPT-N sayılarının derinlikle değişimi Şekil 3'te verilmiştir.

Yapılan sondajlardan, zemin kesitinde üstte kalınlığı 1 5 $\mathrm{m}$ olan dolgu tabakası altında kalınlığ 1 yer yer 20 m'ye ulaşan killi veya siltli kum birimler ile siltli çakıl tabakasının yer aldığı anlaşılmaktadır. Kum tabakası içinde SPT-N sayıları 10 20 arasında değişmekte, daha sonra derinlikle artarak 20 40 arasında değerler almaktadır. Sondajlarda yer altı su seviyesinin zemin yüzeyinden itibaren ortalama $5 \mathrm{~m}$ derinlikte ölçüldüğü belirtilmektedir. Sondajlar, arazi penetrasyon deneyleri, tekil ve eş zamanlı mikrotremor ölçümlerinden bulunan sonuçlar birlikte değerlendirilerek bir boyutlu dinamik analizlerde kullanılacak zemin modelleri oluşturulmuştur. Çalışma kapsamında yapılmış olan bir boyutlu dinamik analizlerde kullanılmak üzere, oluşturulan zemin modellerinde yüzeye yakın zemin tabakalarının kayma dalgası hızının derinlikle değişimi SPT-N sayısına bağlı olarak belirlenmiştir [7].

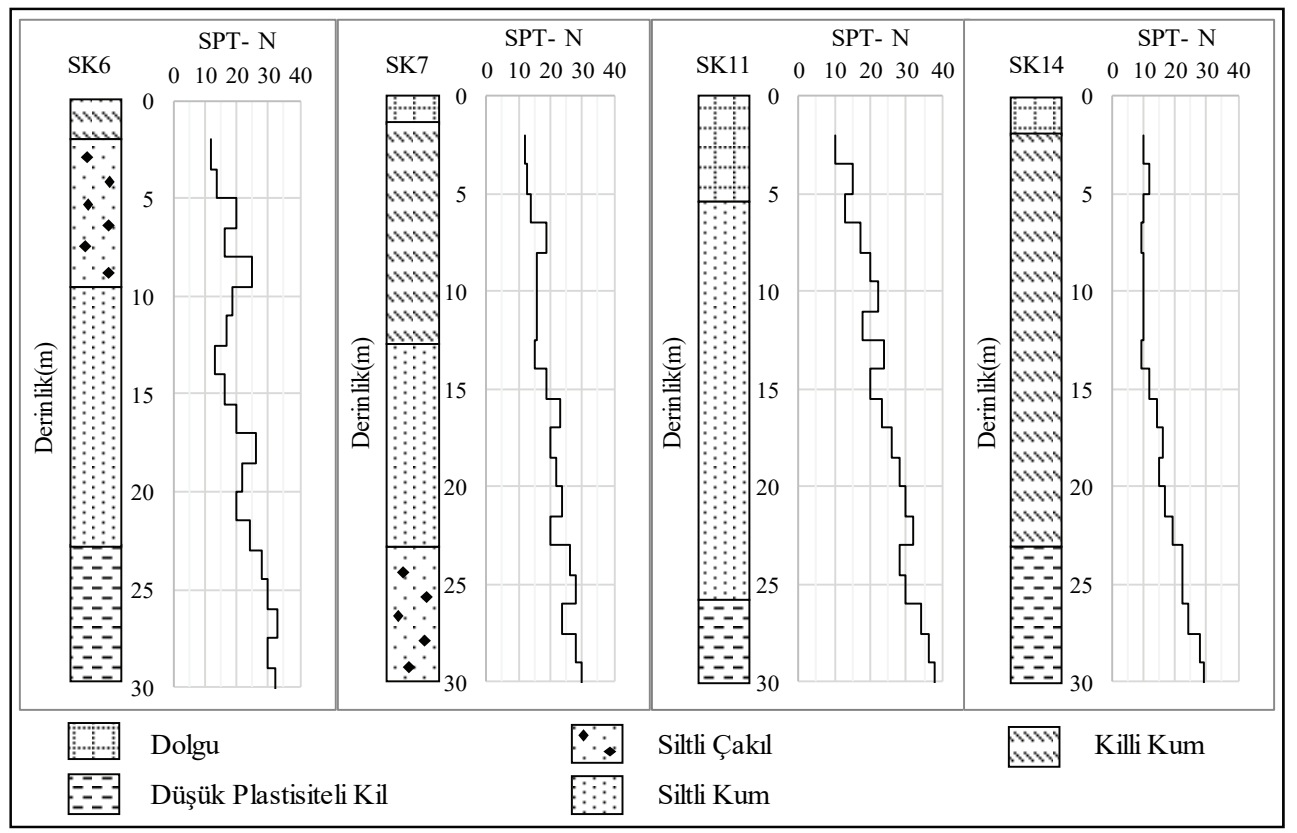

Şekil 3 - Sondajlardan Elde Edilen Zemin Kesiti ve SPT-N Sayılarının Derinlikle Değişimi

\subsection{Eş Zamanlı Çoklu Mikrotremor Ölçümleri ve Kayma Dalgası Hızı}

Mikrotremorlar 0.01 20 saniye arasında değişen periyotlara ve $10^{-2}-10^{-3} \mathrm{~mm}$ arasında değişen genliklere sahip doğal ve yapay kaynak etkisindeki titreşimlerdir. Geoteknik mühendisliğinde tekil mikrotremor ölçümleri, hakim periyot ve büyütme gibi zemin tabakalarının dinamik davranış özelliklerini belirlemede kullanılırken, eş zamanlı mikrotremor ölçümleriyle de kayma dalgası hızının derinlikle değişimi ve sismik anakaya 
derinliği belirlenebilmektedir [8, 9]. Ölçüm süresinin göreli kısalığı, uygulama kolaylığı ve düşük maliyeti; mikrotremor ölçümlerinin geoteknik deprem mühendisliğindeki kullanılabilirliğini arttırmıştır. Derin alüvyonda kayma dalgası hızının $\left(V_{s}\right)$ derinlikle değişimini belirlemek için; mikro titreşimlerin çoklu alıcılarla yapılan dizi ölçümüne dayanan pasif kaynaklı yüzey dalgası yöntemleri tercih edilmektedir. Mikrotremorların oluşturduğu yüzey dalgalarının farklı frekanslarda farklı faz hızlarında harmonik dalgalardan meydana geldiği bilinmektedir. Yüzey-Rayleigh dalgası ölçümlerine dayalı yöntemlerin temelini dalga boylarının frekansa veya periyoda bağımlı olması oluşturmaktadır [10]. Diğer bir deyişle periyodu yüksek dalga bileşenlerinin derinde yer alan zemin tabakalarının, düşük periyotlu dalgaların ise yüzey yakın zemin tabakalarının dinamik davranışı hakkında bilgi sağladığı bilinmektedir. Zemin tabakalarının kayma dalgası hızının derinlikle değişimi, uygun frekans davranışına sahip alıcıların $5 \sim 50 \mathrm{~m}$ arasında değişen açıklıklarda yerleştirilmesiyle oluşturulan çoklu mikrotremor ölçüm ağları kullanılarak eş zamanlı olarak alınan yaklaşık 10 20 dakika uzunluğundaki kayıtların analizi ile belirlenebilmektedir [11]. Eş zamanlı çoklu mikrotremor ağ ölçüm yönteminde, mikrotremorların düşey bileşenleri kullanılarak, ağ içerisindeki her iki alıcı arasında ikili korelasyonlar oluşturularak spektral analizler yapılmaktadır.

Bu çalışmada, bir eşkenar üçgenin köşe noktaları ile kenarlarının orta noktalarına ve merkeze yerleştirilen toplam 7 adet alıcı ile oluşturulan düzende, 15 dakika süre ile eş zamanlı kayıtlar alınmıştır. İncelenen bölgede ölçüm yapılan her nokta için zemin tabakalarına ait faz hızlarının değişimini gösteren dispersiyon eğrileri elde edilmiştir. Sonrasında, dispersiyon eğrilerinin ters dönüşümüyle kayma dalgası hızlarının derinlikle değişimleri belirlenmiştir. Ölçümlerde kullanılan alıcılar, kayıt örneği, analizler sonucunda elde edilen dispersiyon eğrisi ve kayma dalgası hızının derinlikle değişimi Şekil 4 'te gösterilmiştir.

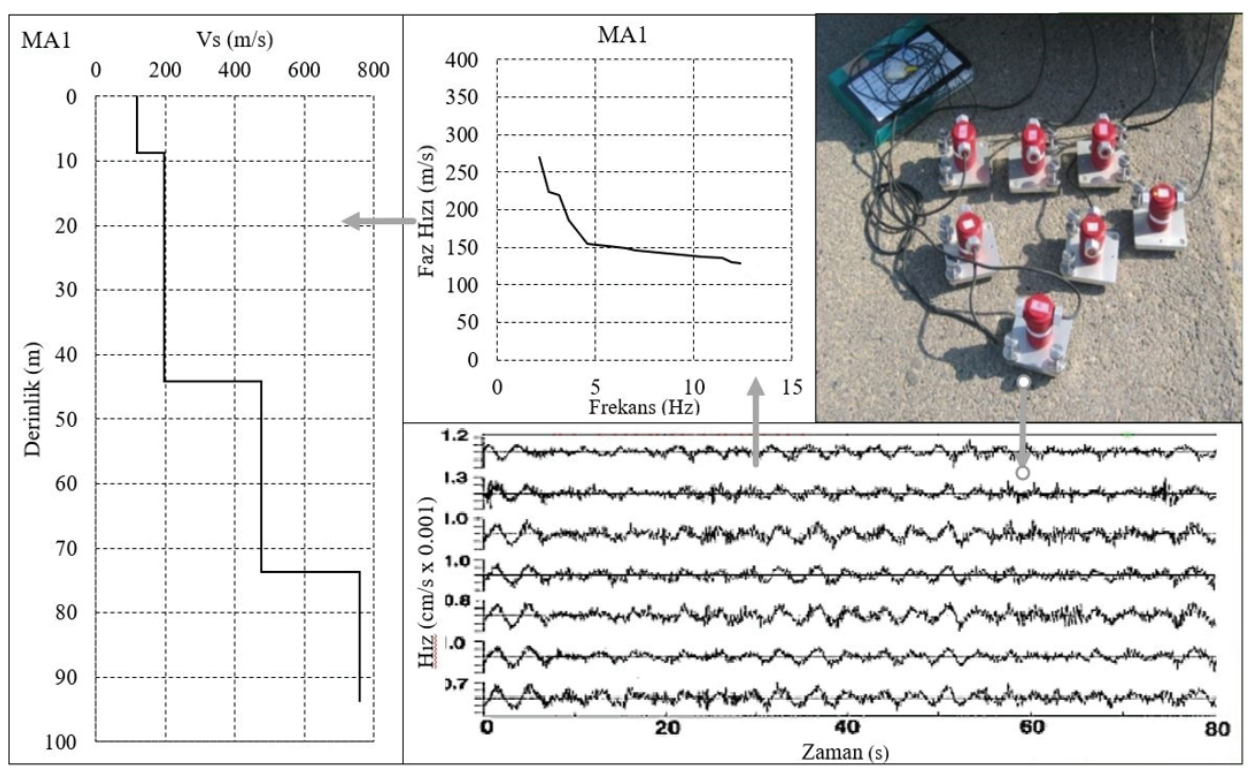

Şekil 4 - Arazide Yapılan Eş Zamanlı Mikrotremor Ölçümleri 
Arazi çalışmaları sonucunda elde edilen kayıtların analiz edilmesi sonucunda; zemin tabakalarına ait Rayleigh dalgası faz hızları elde edilmiştir. İkili korelasyon katsayılarından ters çözüm yapılarak kayma dalgası faz hızlarının belirlenmesi üzerine Aki (1957) tarafından geliştirilen yöntemde; ikili korelasyon katsayılarının elde edilmesi için oluşturulan bağıntı, Denklem 1'de verilmiştir.

$\rho(r, \omega)=\frac{1}{2 \pi \varphi(r=0, \omega)} \int_{0}^{2 \pi} \varphi(r, \theta, \omega) d \theta$

Denklemde; $\varphi(r=0, \omega)$, ortadaki ortalama otokorelasyonu ve $\varphi(r, \theta, \omega)$, iki alıcı arasındaki çapraz korelasyonu ifade eder. Bu yöntemde faz hızları, ikili korelasyon katsayıları $\rho(r, \omega)$ kullanılarak hesaplanmakta; farklı frekans $(\omega)$ değerlerinde, aralarında $r$ kadar mesafe ve ortalama azimuth açısı $(\theta)$ bulunan bütün alıcı çiftleri arasında işlem yapılmaktadır.

Eşzamanlı mikrotremor ağ ölçümünden elde edilen gözlemsel dispersiyon eğrisindeki faz hızları ve eğer varsa sahada yapılmış zemin etüdü sondajlarından elde edilen verilerin birlikte değerlendirilmesi yardımıyla teorik dispersiyon eğrisine altlık teşkil edecek bir boyutlu tabaka modeli oluşturulmaktadır. Bu modelde zemin tabakalarının homojen ortamda yatayda sonsuza uzandığı kabul edilmektedir. En uygun kayma dalgası hızının derinlikle değişiminin belirlenebilmesi amacıyla kullanılan ters çözüm yöntemi; gözlenen faz hızları ve tabakalı zemin modeli kullanılarak hesaplanan faz hızları arasındaki karesel farkların toplamı olan Misfit fonksiyonunun $\left(\mathrm{E}_{\mathrm{i}}\right)$ en aza indirgenmesi esasına dayanır. Misfit fonksiyonu $\left(\mathrm{E}_{\mathrm{i}}\right)$ Denklem 2 ile gösterildiği gibidir.

$E_{i}=\frac{1}{N} \sum_{i=1}^{N}\left[v_{i}^{o}-v_{i}^{c}\right]^{2}$

Bağıntıda $\mathrm{N}$ veri sayısını $v_{i}^{o}$ ve $v_{i}^{c}$ gözlenen ve hesaplanan Rayleigh dalgası faz hızlarını göstermektedir. İkili korelasyon katsayılarından faz hızı dispersiyon eğrilerinin elde edilmesi ve Genetik Algoritma yöntemiyle yapılan optimizasyona bağlı ters çözümle kayma dalgası hızının derinlikle değişiminin bulunmasıyla analiz tamamlanmaktadır [12]. Analizler sırasında elde edilen dispersiyon eğrisi ve kayma dalgası hızının derinlikle değişimi 3 ve 6 nolu eş zamanlı mikrotremor kayıtları için Şekil 5 'te gösterilmiştir.

Yapılan çalışma kapsamında belirlenen ve yerleri Şekil 2'de gösterilen 6 ayrı ölçüm alanında 7 alıcı ile eş zamanlı mikrotremor ölçümler yapılmıştır. Her bir yerleşimde alınan kayıtlar analiz edilerek dispersiyon eğrileri elde edilmiştir. Bu eğriler; aynı sahalar için üç bileşenli tekil mikrotremor ölçümleri sonucunda elde edilen H/V Spektral Oran eğrileri ile birlikte değerlendirilmiş, daha sonra ters çözüm yöntemiyle, zemin tabakalarına ait kayma dalgası hızı profilleri belirlenmiştir. Çalışma kapsamında mühendislik anakayası olarak, Eurocode 8'de tanımlanan kayma dalgası hızının $\mathrm{V}_{\mathrm{s}}=800 \mathrm{~m} / \mathrm{s}$ olduğu B sınıfı zemin referans alınmıştır [13]. Eş zamanlı mikrotremor ölçümlerinden elde edilen kayma dalgası hızının derinlikle değişimi incelendiğinde bir boyutlu dinamik analizlerde hassasiyetin artması amacıyla kullanılan SPT-N vuruş sayıları ile belirlenen kayma dalgası hızının derinlikle değişimi ile uyum gösterdiği tespit edilmiştir. 


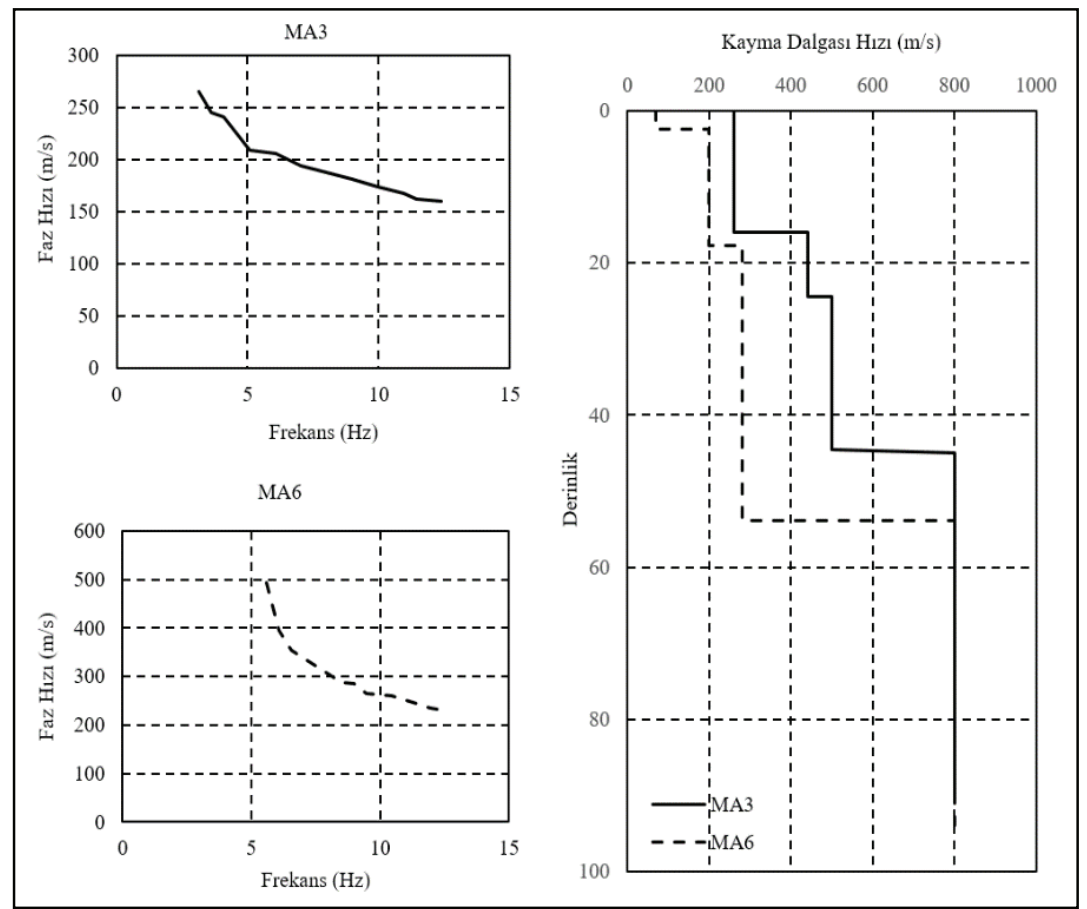

Şekil 5 - Eşzamanlı Mikrotemor Ölçümlerinden Elde Edilen Dispersiyon Ĕgrileri ve Kayma Dalgası Hızının Derinlikle Değişimi

\subsection{Tekil Mikrotremor Ölçümleri}

Mikrotremorlar ile kuvvetli yer hareketinin özellikleri arasında kuramsal farklılık olmasına rağmen, tekil mikrotremor ölçümlerinden ve kuvvetli yer hareketinin sayısal analizinden elde edilen hakim periyot değerleri birbirleriyle uyum göstermektedir [14]. Çalışma kapsamında belirlenen sahalarda yapılan tekil mikrotremor ölçümlerinde üç bileşenli Guralp CMG-40T alıcı ve Guralp CMG-DM24 sayısallaştırıcısından oluşan taşınabilir hızölçer seti kullanılmıştır. Mikrotremor ölçümlerine ait kayıtlar, H/V Spektral Oran yöntemine göre analiz edilerek hakim periyot ve zemin büyütmesi değerleri belirlenmiştir [15].

Yöntemin uygulanması için öncelikle sahada belirlenen 15 ayrı noktada tekil mikrotremor ölçümleri yapılmış üç bileşenli kayıtlar alınmıştır. Alınan kayıtlar; gürültüden arındırılabilmesi amacıyla alt pencerelere ayrılmış, $0.20 \mathrm{~Hz}$ ile $25 \mathrm{~Hz}$ aralığında bant geçiren filtre uygulanmış ve her bir pencere için Fourier genlik spektrumu belirlenmiştir. Kaydı oluşturan iki yatay bileşenin kuadratik ortalaması alınarak her bir pencere için yatay/düşey $(\mathrm{H} / \mathrm{V})$ Spektral Oran eğrisi elde edilmiştir. Bu oranın en büyük olduğu değer zemin büyütmesini $\left(A_{g}\right)$, bu değere karşılık gelen periyot değeri ise hakim periyot değerine $\left(T_{0}\right)$ karşı gelmektedir [16]. Geopsy (2005) yazılımı kullanılarak yapılan H/V Spektral Oran analizlerinden elde edilen sonuçlar her bir ölçüm noktası için Tablo 1'de verilmiştir. 
Bir Boyutlu Dinamik Analiz ve Mikrotremor Ölçüm Sonuçlarının Karşılaştırılması

Tablo 1 - Mikrotremor Ölçümlerinde Elde Edilen Hakim Periyot ve Büyütme Değerleri

\begin{tabular}{cccccc}
\hline Ölçüm No & $\begin{array}{c}\text { Hakim } \\
\text { Periyot } \\
\left(\boldsymbol{T}_{\boldsymbol{0}}\right)\end{array}$ & $\begin{array}{c}\text { Zemin } \\
\text { Büyütmesi } \\
\left(\boldsymbol{A}_{\boldsymbol{g}}\right)\end{array}$ & Ölçüm No & $\begin{array}{c}\text { Hakim } \\
\text { Periyot } \\
\left(\boldsymbol{T}_{\boldsymbol{~}}\right)\end{array}$ & $\begin{array}{c}\text { Zemin } \\
\text { Büyütmesi } \\
\left(\boldsymbol{A}_{\boldsymbol{g}}\right)\end{array}$ \\
\hline MA1 & 0.77 & 4.8 & M05 & 0.63 & 3.4 \\
MA2 & 0.44 & 4.9 & M06 & 0.23 & 5.5 \\
MA3 & 0.38 & 3.9 & M07 & 0.37 & 3.9 \\
MA4 & 0.44 & 6.2 & M08 & 0.51 & 4.6 \\
MA5 & 0.71 & 3.9 & M09 & 0.10 & 4.9 \\
MA6 & 0.64 & 3.6 & M10 & 0.44 & 6.0 \\
M01 & 0.60 & 5.2 & M11 & 0.24 & 4.5 \\
M02 & 0.65 & 4.0 & M12 & 0.44 & 3.9 \\
M03 & 0.90 & 4.1 & M13 & 0.67 & 4.3 \\
M04 & 0.65 & 2.9 & M14 & 0.41 & 4.0 \\
M05 & 0.63 & 3.4 & M15 & 0.66 & 4.0 \\
\hline
\end{tabular}

Bölgede alınan mikrotremor kayıtlarının analizleri sonucunda hakim periyot değerlerinin $0.24 \sim 0.90$ sn ve zemin büyütmesi değerlerinin ise 2.9 6.2 arasında değiştiği belirlenmiştir. Çalışma sahasında yapılan mikrotremor ölçümlerine ait H/V Spektral Oran analizlerine örnek teşkil etmesi açısından; MA1 ve M10 kayıtlarına ait sonuçlar, düşey eksende zemin büyütmesi değeri $\left(A_{g}\right)$, yatay eksende ise periyot değerleri olmak üzere Şekil 6'da gösterilmiştir.

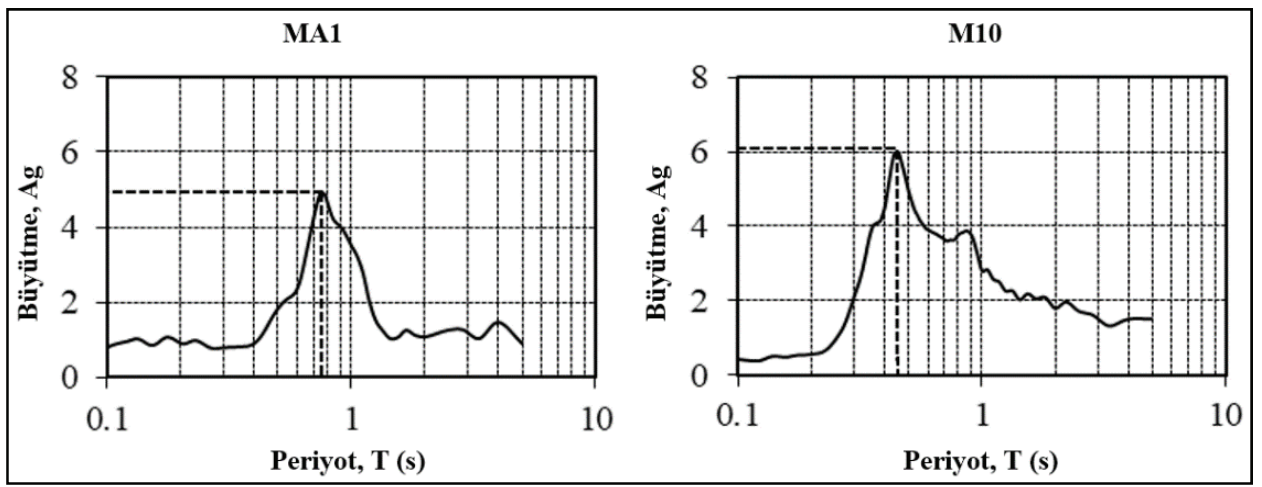

Şekil 6 - MA1 ve M10 Ölçümlerine Ait H/V Spektral Oran Analizi Sonuçları

\subsection{Nakamura İndisi ve Yüzeydeki Efektif Kayma Şekil Değiştirmesi Değerleri}

Nakamura (2008) tarafından önerilmiş olan sismik hasar görebilirlik indisi $\left(K_{g}\right)$, mikrotremor ölçümlerinin analizi sonucunda belirlenen zemin büyütmesi $\left(A_{g}\right)$ ve hakim periyot $\left(T_{0}\right)$ 
değerleri kullanılarak Denklem 3 ile belirlenmektedir. Yüzeye yakın zemin tabakalarında kuvvetli yer hareketi sırasında oluşacak kayma şekil değiştirmeleri $\left(\gamma_{\mathrm{e}}\right)$, hasar görebilirlik indisi ve taban sismik anakayası en büyük yatay ivme değerine bağlı olarak Denklem 4'te verildiği gibi hesaplanabilmektedir.

$$
\begin{aligned}
& K_{g}=A_{g}{ }^{2} T_{0} \\
& \gamma_{e}=K_{g} C a_{b}
\end{aligned}
$$

Nakamura tarafından önerilen bu yöntemde; efektif kayma şekil değiştirmesi değeri $\left(\gamma_{e}\right)$, tekil mikrotremor ölçümünden elde edilen $K_{g}$ değerinin taban sismik anakayası en büyük yatay ivme değeri $\left(a_{b}\right)$ ve $C$ katsayısı ile çarpılması ile elde edilmektedir. Bağıntıdaki $C$ katsayısı ise kuvvetli yer hareketinin verimliliğini tanımlayan $(e)$ katsayısı ile taban sismik anakayasındaki kayma dalgası hızına $\left(V_{b}\right)$ bağlı olarak Denklem 5'e göre hesaplanmaktadır. Bağıntılarda ivme değeri $\left(a_{b}\right)$ gal, $V_{b}$ ise $\mathrm{cm} / \mathrm{s}$ birimindedir. Verimlilik katsayısı e, deprem sırasında oluşan dinamik kuvvetin statik kuvvete oranı olarak tanımlanmış olup, $e=0.60$ olarak verilmektedir [4].

$$
C=\frac{e}{\pi^{2} V_{b}}
$$

$\mathrm{Bu}$ çalışmada zemin dinamik davranış analizleri, yatay tabakalı serbest zemin modeli çerçevesinde taban kayasında tanımlanan deprem yer hareketi altında doğrusal olmayan dinamik zemin özellikleri esas alınarak yapılmıştır. Serbest zemin modeline ait taban sismik anakayasında giriş hareketi olarak kullanılan ivme değerleri, anakaya mostrasında kaydedilip ölçeklendirilen gerçek deprem kayıtlarından oluşmaktadır [17,18,19,20]. Taban sismik anakayası kayma dalgası hızı $\left(V_{b}\right)$, Eurocode 8'de önerildiği gibi $800 \mathrm{~m} / \mathrm{s}$ alınmıştır. Yukarıdaki bağıntıda $e=0.60$ için $C=7.60 \times 10^{-5} \mathrm{~s} / \mathrm{m}$ elde edilmektedir. Mikrotremor ölçüm noktalarında H/V Spektral Oran yöntemine göre hesaplanan $K_{g}$ değerleri, $C$ katsayısı ile birlikte değerlendirilerek, taban sismik anakaya ivmesinin $\left(a_{b}\right) 0.15 \mathrm{~g}, 0.20 \mathrm{~g}$ ve $0.25 \mathrm{~g}$ değerleri için yüzeye yakın zemin tabakalarındaki kayma birim şekil değiştirmeleri $\left(\gamma_{e}\right)$ hesaplanmış ve sonuçlar $K_{g}$ değerleri ile birlikte Tablo 2'de verilmişstir.

Tablo 2 - Mikrotremor Analiz Sonuçları

\begin{tabular}{ccccc}
\hline \hline \multirow{2}{*}{ Ölçüm No } & Hasar Görebilirlik $\left(K_{g}\right)$ & \multicolumn{3}{c}{ Kayma Birim Şekil Değiştirmesi $\left(\gamma_{e}\right)(\%)$} \\
\cline { 3 - 5 } & & $0.15 \mathrm{~g}$ & $0.20 \mathrm{~g}$ & $0.25 \mathrm{~g}$ \\
\hline MA1 & 17.7 & 0.198 & 0.264 & 0.33 \\
MA2 & 10.5 & 0.118 & 0.157 & 0.197 \\
MA3 & 5.7 & 0.064 & 0.085 & 0.106 \\
MA4 & 17.3 & 0.194 & 0.258 & 0.323 \\
MA5 & 11.1 & 0.124 & 0.165 & 0.206 \\
MA6 & 8.5 & 0.096 & 0.127 & 0.159 \\
\hline
\end{tabular}


Tablo 2 - Mikrotremor Analiz Sonuçları (devam)

\begin{tabular}{lcccc}
\hline \hline \multirow{2}{*}{ Ölçüm No } & Hasar Görebilirlik $\left(K_{g}\right)$ & \multicolumn{3}{c}{ Kayma Birim Şekil Değiştirmesi $\left(\gamma_{e}\right)(\%)$} \\
\cline { 3 - 5 } M01 & 16.6 & $0.15 \mathrm{~g}$ & $0.20 \mathrm{~g}$ & $0.25 \mathrm{~g}$ \\
M02 & 10.4 & 0.1165 & 0.247 & 0.309 \\
M03 & 14.8 & 0.166 & 0.154 & 0.193 \\
M04 & 5.3 & 0.059 & 0.221 & 0.276 \\
M05 & 7.5 & 0.083 & 0.111 & 0.099 \\
M06 & 6.8 & 0.076 & 0.101 & 0.139 \\
M07 & 5.7 & 0.063 & 0.085 & 0.126 \\
M08 & 10.7 & 0.120 & 0.160 & 0.106 \\
M09 & 2.5 & 0.028 & 0.037 & 0.200 \\
M10 & 15.8 & 0.177 & 0.236 & 0.046 \\
M11 & 5.0 & 0.056 & 0.075 & 0.294 \\
M12 & 6.6 & 0.073 & 0.098 & 0.093 \\
M13 & 12.2 & 0.137 & 0.182 & 0.122 \\
M14 & 6.5 & 0.073 & 0.097 & 0.228 \\
M15 & 10.7 & 0.120 & 0.160 & 0.121 \\
\hline
\end{tabular}

Mikrotremor ölçümleri sonrasında yapılan analizler sonucunda çalışma sahaları için Hasar Görebilirlik İndisi $\left(K_{g}\right)$ değerleri 2.5 17.7 arasında değiştiği hesaplanmıştır. Kayma birim şekil değiştirmelerin $\left(\gamma_{e}\right)$ ise en büyük taban sismik anakaya ivmesine bağlı olarak \%0.059 ile \%0.330 arasında değiştiği belirlenmiştir.

\section{ZEMIN TABAKALARININ BİR BOYUTLU DINAMİK ANALİİ}

Çalışma bölgesindeki önceden yapılan zemin araştırmalarından derlenen sondaj verilerinin arazide yapılan ölçümlerden elde edilen kayma dalgası hızı profilleriyle birlikte değerlendirilmesi sonucunda zemin modelleri oluşturulmuştur. Bu zemin modellerinin farklı anakaya mostrası ivme değerlerine sahip kuvvetli yer hareketi karşısındaki davranışı, bir boyutlu (1D) dinamik analizler yardımıyla belirlenmiştir. 1D dinamik analizler, eşdeğer doğrusal yöntem kullanılarak DeepSoil V6.1 yazılımıyla yapılmıştır [21].

\subsection{Malzeme Modeli}

Yapılan eşdeğer doğrusal analizlerde kullanılan birim kayma şekil değiştirmesi seviyesine bağlı normalize kayma modülü $\left(\mathrm{G} / \mathrm{G}_{\text {maks }}\right)$ ve sönüm oranı (D) değişim eğrileri, ince daneli zeminler için Vucetic ve Dobry (1991), kaba daneli zeminler içinse Seed ve Idriss (1970) 
tarafından önerilen bağıntıların ortalama değerleri kullanılarak oluşturulmuştur. Analizlerde kullanılan rijitlik azalım ve sönüm oranı eğrileri plastisite indisleri farklı zeminler için Şekil 7'de gösterilmiştir [22, 23].

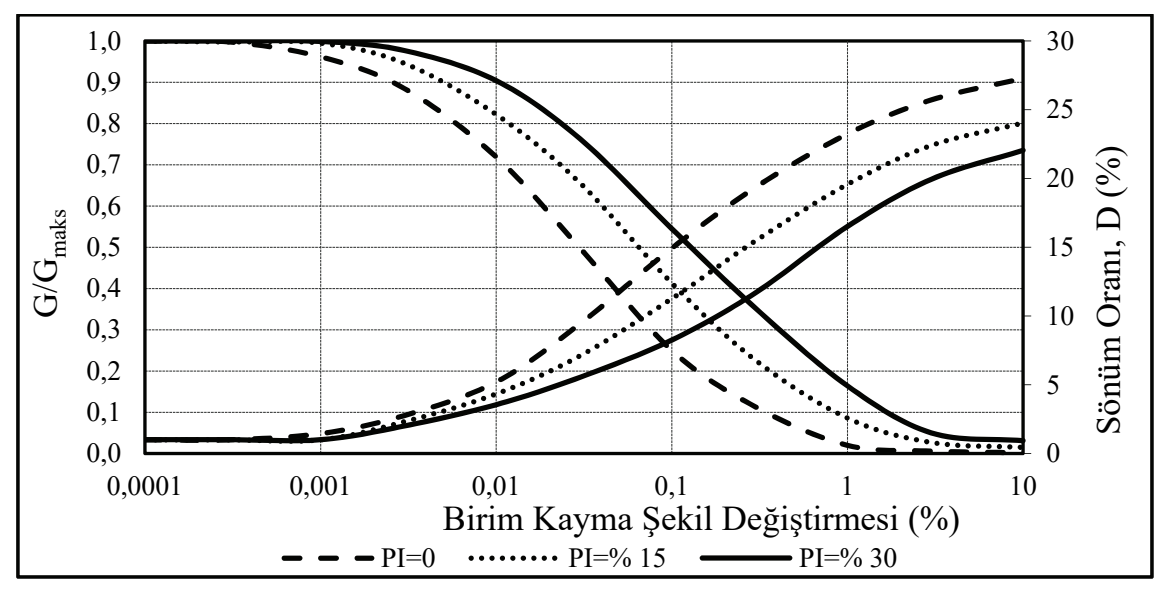

Şekil 7 - 1D Dinamik Analizlerde Kullanılan Rijitlik Azalımı $\left(G / G_{\text {maks }}\right)$ ve Sönüm Oranı (D) Değişim Ĕgrileri

\subsection{Kuvvetli Yer Hareketi Kayıtları}

Deprem hareketine bağlı risk seviyesinin yüksek olduğu çalışma sahasında sismik anakayadaki deprem hareketinin şiddetinde meydana gelecek değişimin zemin tabakalarının dinamik davranışına etkisinin belirlenebilmesi amacıyla yapılan bir boyutlu dinamik analizlerde; ölçeklendirilmiş en büyük mutlak ivme değerleri ( $\mathrm{a}_{\text {maks }}$ kaya $) 0.3 \mathrm{~g}$ ile $0.5 \mathrm{~g}$ arasında değişen, 14 farklı anakaya mostrası ivme kaydı kullanılmıştır [24].

Vanmarcke (1979), ölçeklendirme faktörünün; doğrusal elastik yapısal problemlerin analizinde Krinitszky ve Chang (1979) tarafindan önerilen 0.25 ile 4 sınır değerleri arasında seçilebileceğini, bununla birlikte zemin tabakalarında kuvvetli yer hareketine bağlı taşıma gücü kaybı, şev duraylılığı problemi ve sıvılaşma olgusunun incelendiği kayma birim şekil değiştirmesi seviyelerinin yüksek olduğu dinamik analizlerde 0.5 ile 2 değerleri arasında kalması gerektiğini belirtmiştir. Bu çalı̧̧mada yapılan 1D dinamik analizlerde Vanmarcke (1979) tarafından sunulan öneri dikkate alınmıştır [25, 26].

Seçilen deprem hareketi kayıtlarına ait ölçeklendirilmemiş ivme zaman geçmişleri Şekil 8'de ve bunlara ait özellikler ise Tablo 3'te verilmiştir. Seçilen ivme kaydının ait olduğu deprem, kayıt bileşeni, büyüklüğü, şiddet parametreleri ve diğer karakteristik özellikler Tablo 3'te detaylı bir şekilde belirtilmiştir. $0.4 \mathrm{~g}$ değerine ölçeklendirilmiş ivme kayıtlarına ait normalize edilmiş ivme spektrumları Şekil 9'da gösterilmiştir. 


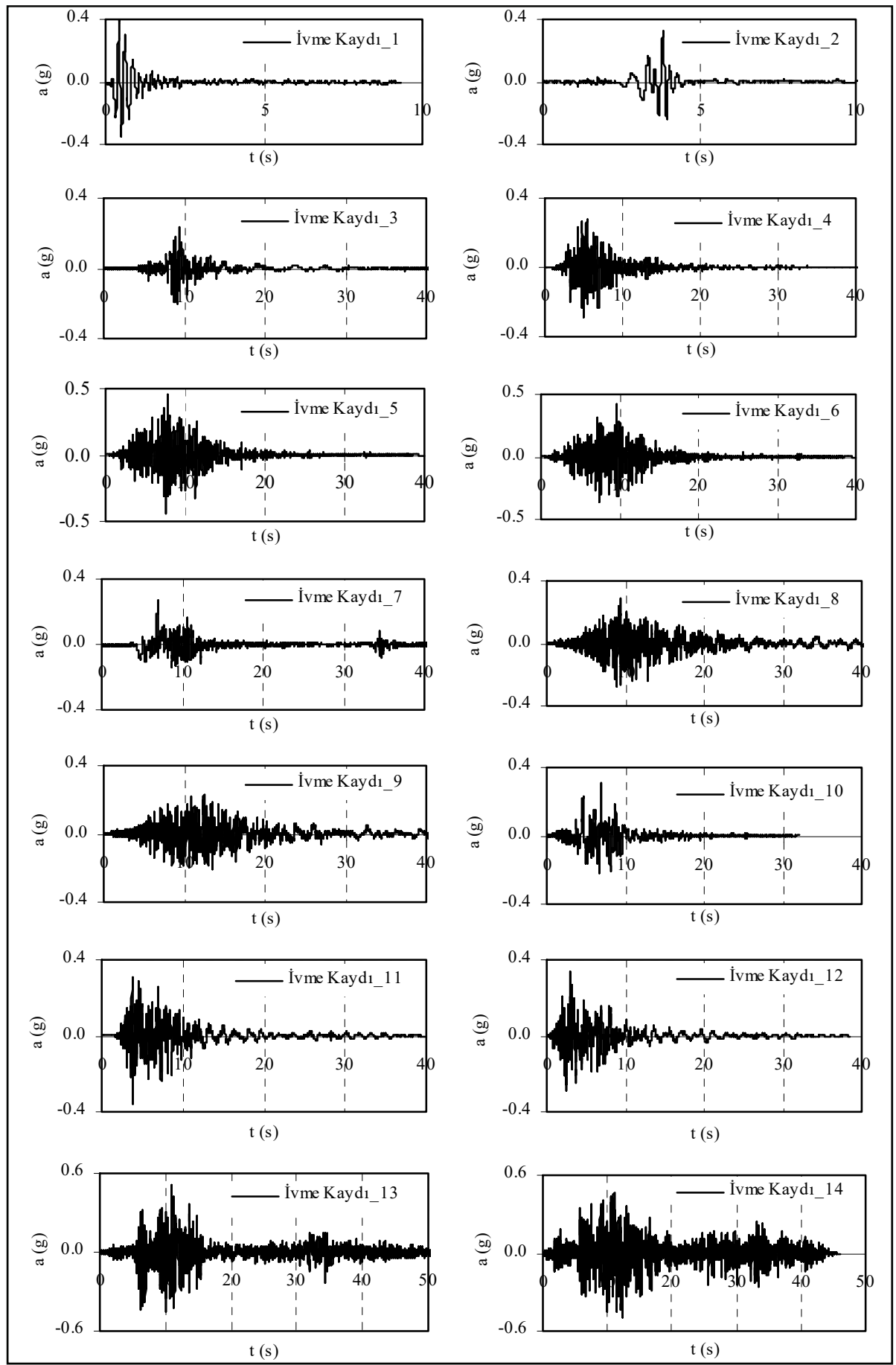

Şekil 8 - Bir Boyutlu Dinamik Analizlerde Kullanılan Anakaya Mostrası İvme Kayıtları 
Tablo 3 - Analizlerde Kullanılan Deprem Hareketlerinin Özellikleri

\begin{tabular}{lccccc}
\hline \hline Deprem & $\begin{array}{c}\text { İzmir, } \\
\mathbf{1 9 7 7}\end{array}$ & $\begin{array}{c}\text { Kocaeli, } \\
\mathbf{1 3 / 0 9 / 1 9 9 9}\end{array}$ & $\begin{array}{c}\text { Tottori, } \\
\mathbf{2 0 0 0}\end{array}$ & $\begin{array}{c}\text { Northridge, } \\
\mathbf{1 9 9 4}\end{array}$ & $\begin{array}{c}\text { Loma } \\
\text { Prieta, 1989 }\end{array}$ \\
\hline İvme Kaydi No & 1 & 2 & 3 & 4 & 5 \\
Bileşen & $\mathrm{K}-\mathrm{G}$ & $\mathrm{D}-\mathrm{B}$ & $\mathrm{D}-\mathrm{B}$ & 90 & 0 \\
$\mathrm{~V}_{\mathrm{s} 30}(\mathrm{~m} / \mathrm{s})$ & 771 & 826 & 967 & 715 & 714 \\
Büyüklük & $\mathrm{M}_{\mathrm{w}}=5.6$ & $\mathrm{M}_{\mathrm{d}}=5.7$ & $\mathrm{M}_{\mathrm{w}}=6.6$ & $\mathrm{M}_{\mathrm{w}}=6.7$ & $\mathrm{M}_{\mathrm{w}}=6.9$ \\
$\Delta(\mathrm{km})$ & 9.5 & 10.5 & 31.4 & 14.7 & 16.3 \\
$\mathrm{a}_{\text {maks }}(\mathrm{g})$ & 0.39 & 0.32 & 0.25 & 0.29 & 0.45 \\
ASI $(\mathrm{cm} / \mathrm{s})$ & 260.5 & 261.2 & 263.7 & 278.8 & 438.3 \\
VSI $(\mathrm{cm})$ & 39.8 & 54.1 & 73.1 & 81.7 & 91.1 \\
SMA $(\mathrm{g})$ & 0.09 & 0.10 & 0.19 & 0.23 & 0.38 \\
$\mathrm{~T}_{\mathrm{m}}(\mathrm{s})$ & 0.22 & 0.32 & 0.50 & 0.33 & 0.28 \\
\hline \hline
\end{tabular}

\begin{tabular}{|c|c|c|c|c|c|}
\hline Deprem & $\begin{array}{l}\text { Loma } \\
\text { Prieta, } \\
1989\end{array}$ & $\begin{array}{l}\text { Kocaeli, } \\
\text { 17/08/1999 }\end{array}$ & Iwate, 2008 & Iwate, 2008 & Kobe, 1995 \\
\hline İvme Kaydı No & 6 & 7 & 8 & 9 & 10 \\
\hline Bileşen & 90 & $\mathrm{~K}-\mathrm{G}$ & $\mathrm{K}-\mathrm{G}$ & D-B & 90 \\
\hline $\mathrm{V}_{\mathrm{s} 30}(\mathrm{~m} / \mathrm{s})$ & 714 & 701 & 826 & 826 & 1043 \\
\hline Büyüklük & $\mathrm{M}_{\mathrm{w}}=6.9$ & $\mathrm{M}_{\mathrm{d}}=7.4$ & $\mathrm{M}_{\mathrm{w}}=6.9$ & $\mathrm{M}_{\mathrm{w}}=6.9$ & $\mathrm{M}_{\mathrm{w}}=6.9$ \\
\hline$\Delta(\mathrm{km})$ & 16.3 & 40.0 & 23.2 & 23.2 & 25.4 \\
\hline $\mathrm{a}_{\text {maks }}(\mathrm{g})$ & 0.40 & 0.23 & 0.23 & 0.28 & 0.31 \\
\hline ASI (cm/s) & 348.9 & 187.0 & 219.6 & 217.8 & 241.5 \\
\hline VSI (cm) & 63.1 & 73.6 & 101.5 & 117.2 & 141.7 \\
\hline SMA (g) & 0.33 & 0.17 & 0.21 & 0.24 & 0.20 \\
\hline $\mathrm{T}_{\mathrm{m}}(\mathrm{s})$ & 0.22 & 0.67 & 0.52 & 0.57 & 0.70 \\
\hline Deprem & $\begin{array}{c}\text { Laquila, } \\
2009\end{array}$ & $\begin{array}{c}\text { Laquila, } \\
2009\end{array}$ & $\begin{array}{c}\text { Manjil, } \\
1990\end{array}$ & $\begin{array}{c}\text { Manjil, } \\
1990 \\
\end{array}$ & \\
\hline İvme Kaydı No & 11 & 12 & 13 & 14 & \\
\hline Bileşen & K-G & D-B & 0 & 90 & \\
\hline $\mathrm{V}_{\mathrm{s} 30}(\mathrm{~m} / \mathrm{s})$ & 717 & 717 & 724 & 724 & \\
\hline Büyüklük & $\mathrm{M}_{\mathrm{w}}=6.3$ & $\mathrm{M}_{\mathrm{d}}=6.3$ & $\mathrm{M}_{\mathrm{w}}=7.4$ & $\mathrm{M}_{\mathrm{w}}=7.4$ & \\
\hline$\Delta(\mathrm{km})$ & 1.8 & 1.8 & 40.4 & 40.4 & \\
\hline $\mathrm{a}_{\text {maks }}(\mathrm{g})$ & 0.34 & 0.34 & 0.51 & 0.49 & \\
\hline ASI (cm/s) & 242.6 & 219.6 & 492.9 & 486.6 & \\
\hline VSI (cm) & 151.4 & 140.2 & 155.8 & 216.6 & \\
\hline SMA (g) & 0.25 & 0.25 & 0.44 & 0.46 & \\
\hline $\mathrm{T}_{\mathrm{m}}(\mathrm{s})$ & 0.66 & 0.69 & 0.32 & 0.32 & \\
\hline \multicolumn{6}{|c|}{$\begin{array}{l}\mathrm{V}_{\mathrm{s} 30} \text { : İstasyon Ortalama Kayma Dalgası Hızı, } \Delta: \text { Merkez Üssü Uzaklığı, } \mathrm{M}_{\mathrm{w}} \text { : Moment } \\
\text { Büyüklüğü, Md: Süre Büyüklügüu, amaks: En Büyük İvme, ASI: İvme Spektrumu Şiddeti, VSI: } \\
\text { Hız Spektrumu Şiddeti (Von Thun vd., 1988), SMA: En Büyük Sürekli İvme (Nuttli, 1979), } \\
\mathrm{T}_{\mathrm{m}} \text { : Ortalama Periyot (Rathje vd., 1998) [27, 28, 29]. }\end{array}$} \\
\hline
\end{tabular}




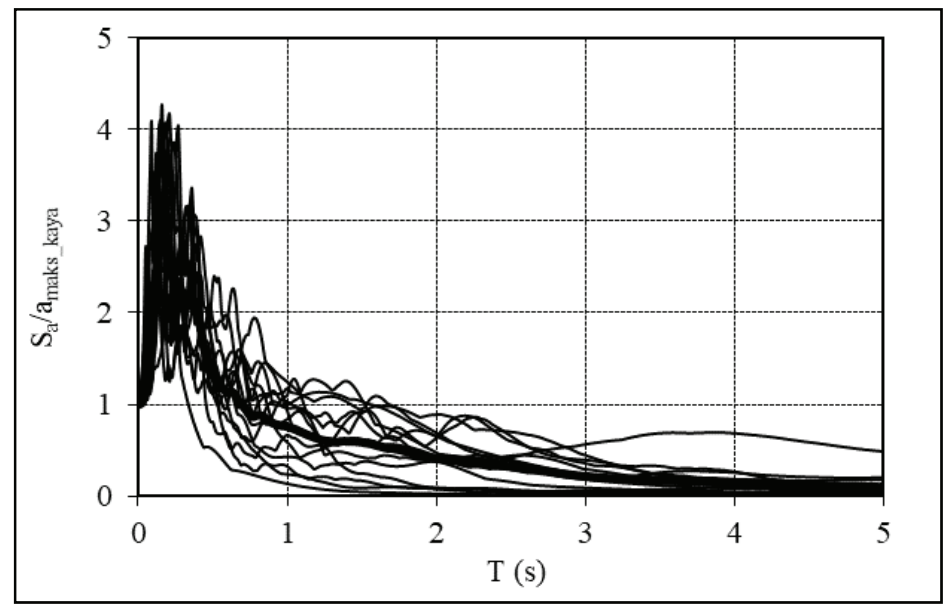

Şekil 9 - 0.4 g En Büyük İvme Değerine Ölçeklendirilmiş Anakaya Mostrası Ivme Kayıtlarına Ait Normalize Edilmiş İve Spektrumları

\subsection{Analiz Sonuçları}

Zemin etüdü sondajlarından elde edilen verilerin ve eş zamanlı mikrotremor ölçümlerinden belirlenen kayma dalgası hızı profillerinin birlikte değerlendirilmesiyle oluşturulan 22 ayrı zemin modeli üzerinde, farklı şiddetlere sahip olacak biçimde ölçeklendirilmiş 14 farklı anakaya mostrası ivme-zaman geçmişi kullanılarak $\left(a_{\text {maks_kaya }}=0.3 \sim 0.5 \mathrm{~g}\right)$ bir boyutlu dinamik analizler düzenlenmiş ve zemin tabakalarının dinamik davranışı belirlenmiştir. En büyük ivme değeri $0.4 \mathrm{~g}$ olacak biçimde ölçeklendirilmiş sismik anakaya mostrası kayıtlarının kullanılmasıyla elde edilen elastik ivme spektrumları MA1 ve SK15 sahaları için sırasıyla Şekil 10 ve Şekil 11'de gösterilmiştir.

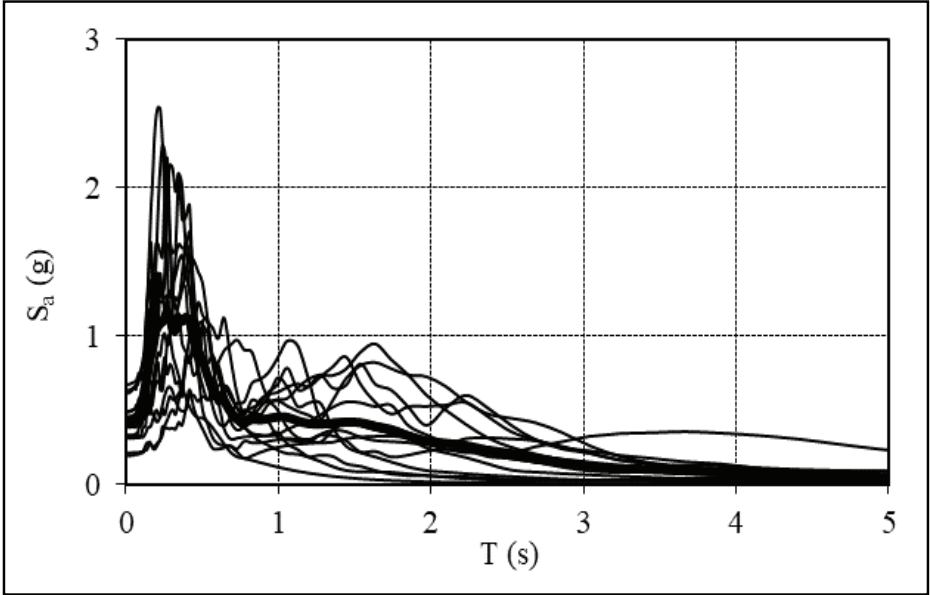

Şekil 10 - 0.4 g En Büyük İvme Değerine Ölçeklendirilmiş Anakaya Mostrası Kayıtlarının Kullanılmasıyla MA1 Sahası için Elde Edilen Elastik Ivme Spektrumları 


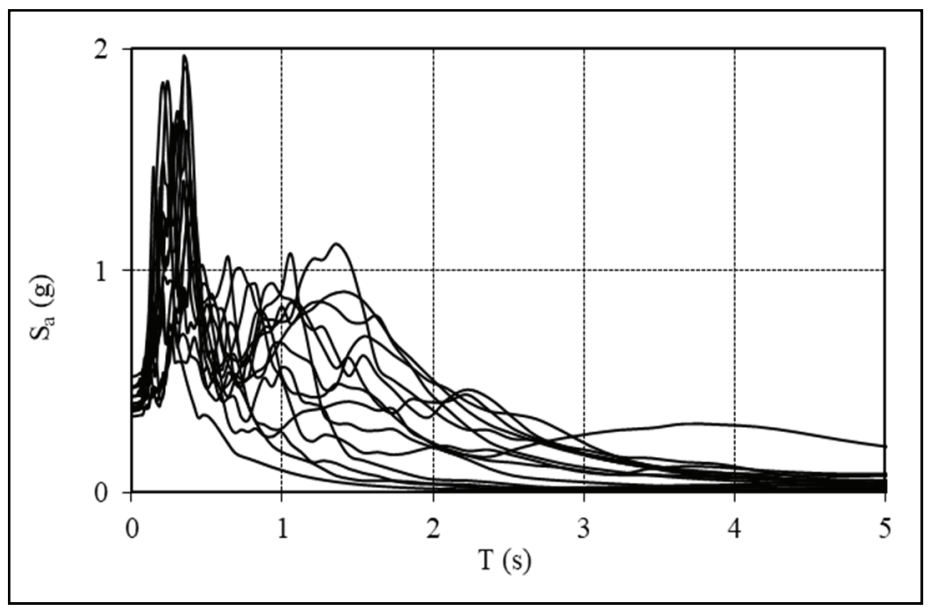

Şekil 11 - 0.4 g En Büyük İvme Değerine Ölçeklendirilmiş Anakaya Mostrası Kayıtlarının Kullanılmasıla SK15 Sahası için Elde Edilen Elastik Ivme Spektrumları

\section{KAYMA ŞEKIL DEĞIŞTIRMELERINININ KARŞILAŞTIRILMASI}

Çalışma sahasında farklı noktalar için elde edilen üç bileşenli tekil mikrotremor kayıtlarının analizi sonrasında Nakamura yönteminin kullanılmasıyla farklı şiddetteki sismik anakaya ivme değerleri için yüzeye yakın zemin tabakalarındaki kayma şekil değiştirmeleri $\left(\gamma_{e}\right)$ elde edilmiştir. Yine aynı ölçüm noktalarını temsil eden zemin kesitleri için farklı şiddetteki anakaya mostrası ivme zaman geçmişi kayıtları kullanılarak 1D eşdeğer lineer analizler düzenlenmiş ve zemin yüzeyinden $5 \mathrm{~m}$ derinlikteki en büyük kayma şekil değiştirmesi değerleri $\left(\gamma_{I D}\right)$ elde edilmiştir. İzotropik, elastik ortamda düşey olarak ilerleyen kayma dalgaları serbest yüzeye ulaştıklarında kayma gerilmesi ve dolayısıyla kayma şekil değiştirmesinin yok olması, çalışma sahasındaki altyapı hatlarının zemin yüzeyinden $3 \sim 5 \mathrm{~m}$ derinlikte yer alması ve bölgedeki yapıların genelde tek tam bodrumlu sığ temellere sahip olması gibi nedenlerden dolayı; en büyük kayma birim şekil değiştirmesi değerlerinin $\left(\gamma_{I D}\right)$, zemin yüzeyinden itibaren $5 \mathrm{~m}$ derinlik için hesaplananları seçilmiştir. Tekil mikrotremor ölçümleri ve 1D dinamik analizlerden aynı inceleme sahası için elde edilen kayma şekil değiştirmesi değerleri arasındaki ilişki belirlenirken; eşleştirilen kayma deformasyonu değerlerinin, eşdeğer şiddetteki anakaya deprem hareketi kullanılarak hesaplanmış olmasına dikkat edilmiştir. Bir boyutlu eşdeğer doğrusal dinamik analizlerden elde edilen kayma birim şekil değiştirmeleri ile tekil mikrotremor ölçümlerinden elde edilen kayma birim şekil değiştirmeleri arasındaki ilişki, ölçeklendirilmiş en büyük taban sismik anakaya ivmesinin $\left(a_{b}\right)$ farklı değerleri için sırasıyla Şekil 12, Şekil 13 ve Şekil 14'te gösterilmiştir. Daha sonra ivme-zaman geçmişleri Şekil 8'de ve kuvvetli yer hareketi özellikleri Tablo 3'te verilen anakaya mostrasına ait ölçeklendirilmemiş ivme kayıtlarının kullanılmasıyla düzenlenen bir boyutlu eşdeğer doğrusal dinamik analizlerden elde edilen kayma birim şekil değiştirmeleri $\left(\gamma_{I D}\right)$ ile mikrotremor ölçümlerinin Nakamura yöntemine göre analiziyle hesaplanan kayma birim şekil değiştirmeleri $\left(\gamma_{e}\right)$ arasındaki ilişki Şekil 15'te gösterilmiş ve ilgili regresyon bağıntısı yardımıyla bu çalışmada ulaşılan sonuçlar genelleştirilmiştir. 
Bir Boyutlu Dinamik Analiz ve Mikrotremor Ölçüm Sonuçlarının Karşılaştırılması

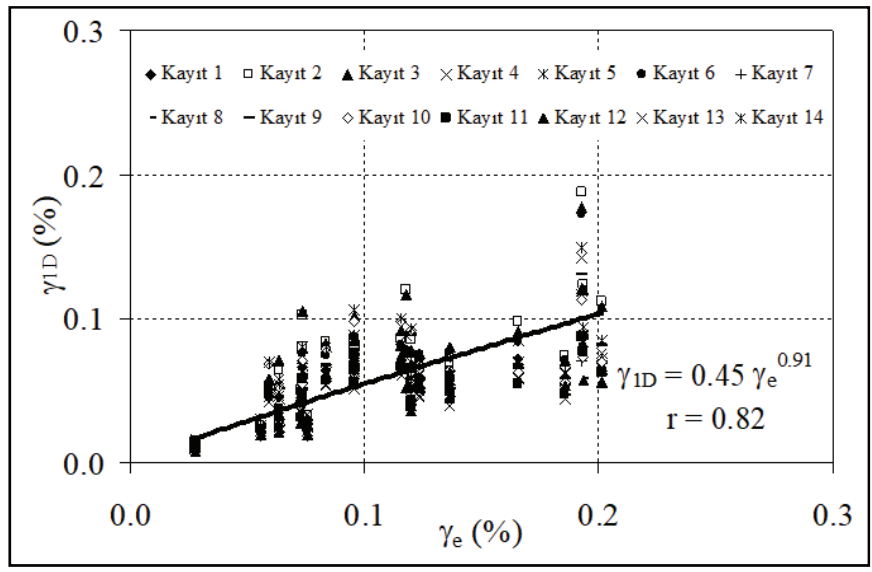

Şekil $12-a_{b}=0.15 \mathrm{~g}$ için Kayma Birim Şekil Değiştirmeleri

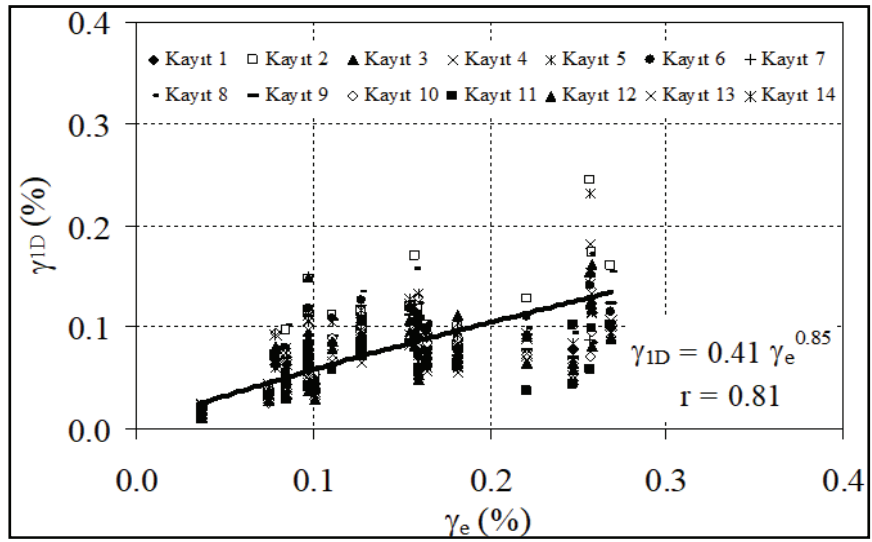

Şekil $13-a_{b}=0.20 \mathrm{~g}$ için Kayma Birim Şekil Değiştirmeleri

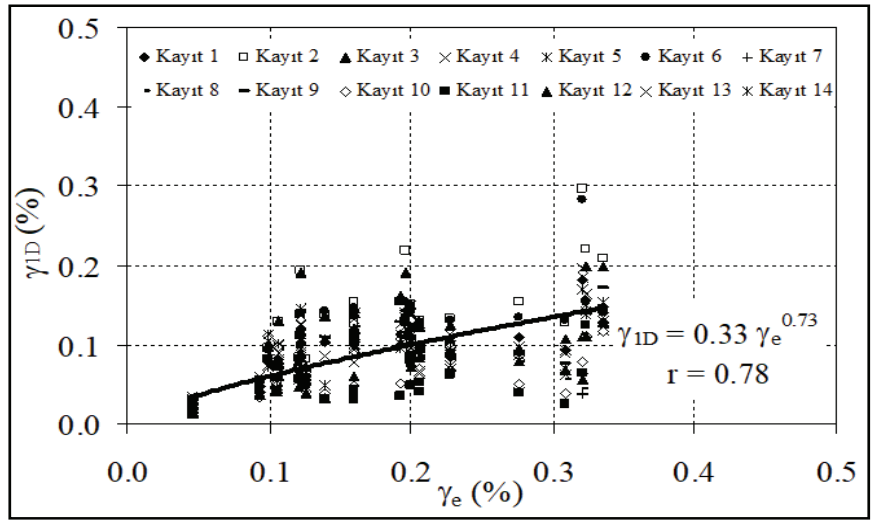

Şekil $14-a_{b}=0.25 \mathrm{~g}$ için Kayma Birim Şekil Değiştirmeleri 


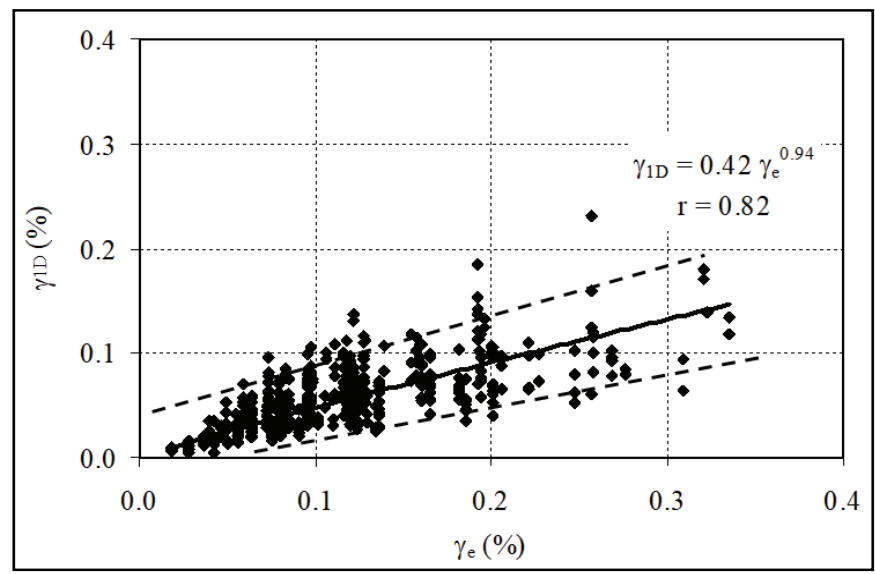

Şekil 15 - Ölçeklendirilmemiş Anakaya Mostrası İvme Kayıtları ile Elde Edilen Kayma Birim Şekil Değiştirmeleri

Çalışma sahalarına ait kayma dalgası hızı profilleri için 14 farklı ölçeklendirilmemiş anakaya mostrası ivme kaydının kullanılmasıyla yapılan bir boyutlu dinamik analizler sonucunda zemin yüzeyinden $5 \mathrm{~m}$ derinlik için elde edilen kayma birim şekil değiştirmeleri $\left(\gamma_{I D}\right)$ ile mikrotremor ölçümlerinin Nakamura Yöntemine göre analiziyle hesaplanan kayma birim şekil değiştirmeleri $\left(\gamma_{e}\right)$ arasında regresyon analizi yapılarak elde edilen bağıntı Denklem 6'da verilmiştir.

$\gamma_{1 D}=5.5 \times 10^{-5}\left(a_{b} A_{g}^{2} T_{0}\right)^{0.94}$

Bağıntıda, $a_{b}$ g cinsinden taban sismik anakayasındaki en büyük yatay ivme, $A_{g}$ ve $T_{0}$ mikrotremor kayıtlarının H/V Spektral Oran yöntemine göre analiziyle elde edilen zemin büyütmesi ve hakim periyot değerlerini göstermektedir.

Tablo 4 - Zemin davranışının kayma deformasyonu seviyesine bağlı değişimi [30].

\begin{tabular}{|c|c|c|c|c|c|}
\hline $\begin{array}{l}\text { Deformasyon } \\
\text { Seviyesi, } \gamma(\%)\end{array}$ & $10^{-4}$ & $10^{-3}$ & $10^{-2}$ & $10^{-1}$ & 10 \\
\hline Olgu & Dalga yayıll & titreşim & & $\begin{array}{l}\text { lar, farklı } \\
\text { urma }\end{array}$ & $\begin{array}{c}\text { Şev kayması, } \\
\text { sıkışma, sıvılaşma }\end{array}$ \\
\hline $\begin{array}{l}\text { Mekanik } \\
\text { Davranış }\end{array}$ & \multicolumn{2}{|c|}{ Elastik } & \multicolumn{2}{|c|}{ Elasto-plastik } & Göçme \\
\hline
\end{tabular}

Bağıntının korelasyon katsayısı $\mathrm{r}=0.82$ olarak hesaplanmıştır. Kullanılan en büyük anakaya mostrası ivme değerinin $0.3 \mathrm{~g}$ ile $0.5 \mathrm{~g}$ arasında değiştiği bu çalışmada elde edilen kayma deformasyonu seviyeleri \%0.02 0.35 aralığında değerlere sahiptir ve Tablo 4 'ten de görülebileceği gibi kuvvetli yer hareketi sırasında yüzeye yakın zemin tabakasında elasto- 
plastik davranışın hakim olacağı anlaşılmaktadır. Verilen bağıntının, zeminde plastik davranış ve göçme durumunun oluşacağı daha yüksek kayma deformasyonu seviyelerini meydana getirecek daha şiddetli yer hareketi ve daha yumuşak veya gevşek zemin koşulları için geçerliliğinin araştırılması gerekmektedir.

\section{SONUÇLAR}

Depremler nedeniyle yüzeye yakın zemin tabakalarında meydana gelen kayma şekil değiştirmelerinin seviyesi, zemin yapılarında oluşabilecek yatay yer değiștirme ve oturma miktarları ile yapılarda oluşan hasar dağılımının yerel değişiminde etkili olmaktadır. Bu çalışmada; küçük genlikli titreşimler olarak bilinen mikrotremor ölçümlerinin Nakamura Yöntemiyle analiz edilmesiyle elde edilen kayma birim şekil değiştirmesi değerleri, kuvvetli yer hareketi karşısında zemin tabakalarının davranışının belirlenmesi amacıyla kullanılan 1D eşdeğer doğrusal dinamik analiz yöntemiyle hesaplanan değerlerle karşılaştırılmıştır.

$\mathrm{Bu}$ amaçla çalışma alanında daha önce zemin araştırma sondajlarının yapıldığı bölgelerde tekil ve eş zamanlı çoklu mikrotremor kayıtları alınmış, eş zamanlı kayıtlar SPAC yöntemi ile analiz edilerek kayma dalgası hızının derinlikle değişimi belirlenmiştir. İnceleme sahası için oluşturulan 22 adet zemin modeli üzerinde 14 farklı anakaya mostrası deprem ivme kaydı kullanılarak bir boyutlu (1D) eşdeğer doğrusal dinamik analizler yapılmış ve yüzey tabakaları için kayma birim şekil değiştirmeleri elde edilmiştir. Yapılan tekil mikrotremor ölçümleri H/V (yatay/düşey) Spektral Oran yöntemine göre analiz edilmiş; zemin büyütmesi ile hakim periyot değerleri, bunlara bağlı hasar görebilirlik indisi değerleri ve taban sismik anakaya ivmesinin farklı değerleri için yüzeye yakın zemin tabakalarındaki kayma birim şekil değiştirmeleri $\left(\gamma_{e}\right)$ hesaplanmıştır.

Mikrotremor ölçümüne dayalı kayma şekil değiştirmesi değerleri $\left(\gamma_{e}\right)$ ile kuvvetli yer hareketine dayalı 1D dinamik analizlerden elde edilen kayma şekil değiştirmesi değerleri $\left(\gamma_{I D}\right)$ arasındaki ilişki, zemin tabakasında elastik ve elasto-plastik davranışın meydana geldiği kayma birim şekil değiştirme seviyeleri için $\gamma_{I D}=5.5 \times 10^{-5}\left(a_{b} A_{g}^{2} T_{0}\right)^{0.94}$ şeklinde üstel bir fonksiyonla ifade edilmiştir. Burada $a_{b}$ g cinsinden taban sismik anakaya ivmesi ve $A_{g}, T_{0}$ sırasıyla mikrotremor ölçümlerinden elde edilen zemin büyütmesi ve hakim periyot değerleridir. Elde edilen bağıntı, bir sahada tasarım yer hareketi özelliklerinin bulunması amacıyla yapılacak bir boyutlu dinamik analizlerde yüzey tabakaları için hesaplanan kayma şekil değiştirmelerinin, hakim periyot ve zemin büyütmesi belirlenerek pratik amaçlar doğrultusunda tahmin edilebilmesinde yararlı görülmektedir. Belli bir bölgede sınırlı sayıda veri kullanılarak elde edilen bağıntının, veri sayısındaki artışla yerel zemin koşullarına bağlı olarak değiştirilmesi ve geliştirilmesi mümkün olacaktır.

\section{Teşekkür}

Yapılan bilimsel çalışmalara desteğinden dolayı Bursa Büyükşehir Belediyesi Fen İşleri Dairesi Başkanlığı Etüd Proje Şube Müdürlüğü’ne ve Jeoloji Mühendisi Ömer GÜLENÇ’e teşekkür ederiz. 


\section{Kaynaklar}

[1] Saita, J., Nakamura, Y. and Sato, T., Liquefaction caused by the 2011 off the Pacific Coast of Tohoku Earthquake and the Result of the Prior Microtremor Measurement, $15^{\text {th }}$ World Conference on Earthquake Engineering, Lisboa, Portugal, 2012.

[2] Atakan, K., Duval, A-M., Theodulidis, N., Guillier B., Chatelain L.,Bard, P-Y. and the SESAME team., The H/V Spectral Ratio Technique: Experimental Conditions, Data Processing and Empirical Reliability Assessment, 13 ${ }^{\text {th }}$ World Conference on Earthquake Engineering, Vancouver, B.C., Canada, 2004.

[3] Chávez-García F. J. and Tejeda-Jácome J., Site response in Tecoman, Colima, Mexico - II Determination of subsoil structure and comparison with observations; J. Soil Dyn. Earthq. Eng. 30(8) 717-723, 2010.

[4] Nakamura, Y., On the H/V Spectrum, The $14^{\text {th }}$ World Conference on Earthquake Engineering in Beijing, China, 2008.

[5] Akyürek, B., 1/500000 Ölçekli Türkiye Jeoloji Haritası: İstanbul Paftası ve Açıklamaları, MTA Gn. Md. Yayını, Ankara, 1987.

[6] Kiper, B., Güzelyalı (Bursa) Yerleşim Amaçlı Temel Sondajları ve Jeolojik ve Jeoteknik İnceleme Raporu, Ankara, 2002.

[7] İyisan, R., Zeminlerde Kayma Dalgası Hızı ile Penetrasyon Deney Sonuçları Arasındaki Bağıntılar, İMO Teknik Dergi, Cilt 7, Sayı 2, ss.1187-1199, 1996.

[8] Leyton, F., Montalva, G. and Ramirez P., Towards a Seismic Microzonation of Concepcion Urban area based on Microtremors, Surface Geology and Damage observed after the Maule 2010 earthquake. First Results, $4^{\text {th }}$ IASPEI/IAEE International Symposium: Effects of Surface Geology on Seismic Motion, University of California, Santa Barbara, 2011.

[9] Burjanek, J., Gassner-Stamm, G., Poggi, V. and Fah D., Estimation of Local Site Effects in the Upper Valais (Switzerland), $4^{\text {th }}$ IASPEI/IAEE International Symposium: Effects of Surface Geology on Seismic Motion,, University of California, Santa Barbara, 2011.

[10] Grutas, R. and Yamanaka, H., Deep Sedimentary Layers in Metro Manila, Philippines Estimated with the Joint Inversion of Receiver Function and Surface Wave Dispersion, $4^{\text {th }}$ IASPEI/IAEE International Symposium: Effects of Surface Geology on Seismic Motion, University of California, Santa Barbara, 2011.

[11] Okada, H., Microtremor Survey Method: SEG Geophysical Monograph Series No. 12, (translated by Koya Suto), Society of Exploration Geophysicists, 2003.

[12] Karagoz O., Chimoto, K., Citak, S., Ozel, O., Yamanaka, H., Hatayama, K., Estimation of shallow S-wave velocity structure and site response characteristics by microtremor array measurements in Tekirdag region, NW Turkey, Earth, Planets and Space, 67:176, 2015.

[13] Eurocode 8, Design of Structures for Earthquake Resistance, Part 1: General Rules, Seismic Actions and Rules for Buildings, 2001. 
[14] İyisan, R., Haşal, M.E., Çekmeceli, M., Bayın, A., Mikrotremor Ölçümlerine Dayalı Bir Mikrobölgeleme Örneği, 5. Geoteknik Sempozyumu, Çukurova Üniversitesi, Adana, 2013.

[15] Mokhberi, M., Tadayon, A. and Rahnema, H., Using the H/V Spectral Ratio of Microtremor for Identification of the Vulnerability of Buildings, Based on Dynamic Site Characteristics of the Shiraz City, $15^{\text {th }}$ World Conf. on Earthquake Engineering, Lisboa, Portugal, 2012.

[16] Okada, H., Theory of Efficient Array Observations of Microtremors with Special Reference to the SPAC Method, Explore Geophys., vol. 37, 73-85, 2006.

[17] Siddiqqi, J., and G., Atkinson Ground motion amplification at rock sites across Canada, as determined from the horizontal-to-vertical component ratio, Bull. Seism. Soc. Am. 92, 877-884, (2002).

[18] Ordonez, G.A., SHAKE 2000 - A Computer Program for the 1-D Analysis of Geotechnical Earthquake Engineering Problems, GeoMotions, LLC:Lacey, Washington, USA, 2012.

[19] Bardet, J.P., Ichii, K. and Lin, C.H., 2000. EERA a Computer Program for Equivalentlinear Earthquake Site Response Analyses of Layered Soil Deposits, Univ. of Southern California, Dep. of Civil Eng., US.

[20] Yoshida, N., Seismic Ground Response Analysis, Springer, $1^{\text {st }}$ ed., 2015.

[21] Hashash, Y.M.A., Musgrove, M.I., Harmon, J.A., Groholski, D.R., Phillips, C. and Park, D., DEEPSOIL 6.1, User Manual, 2016.

[22] Vucetic, M. and Dobry, R., Effect of Soil Plasticity on Cyclic Response, Journal of Geotechnical Engineering, 117:1, 87-107, 1991.

[23] Seed, H.B. and Idriss, I.M., Soil Moduli and Damping Factors for Dynamic Response Analyses, Report EERC, Berkeley CA, USA, University of California, 1970.

[24] Türkiye Cumhuriyeti Bayındırlık ve İskan Bakalığı Afet İşleri Genel Müdürlüğü Deprem Araştırma Dairesi Başkanlığı, Türkiye Deprem Bölgeleri Haritası, İndeks Yerleşim Birimleri ve Deprem Bölgeleri Raporu, Ankara, 1996.

[25] Krinitszky, E.L. and Chang, F.K., State-of-the-art for assessing earthquake hazards in the United States: Specifying peak motions for design earthquakes, Miscellaneous Paper S-73-1, Report 7, U.S Army Corps of Engineers Waterways Experiment Station, Vicksburg, Mississippi, 1979.

[26] Vanmarcke, E.H.,State of the art for assessing earthquake hazards in the United States: Representation of earthquake ground motion: Scaled accelerograms and equivalent response spectra, Miscellaneous Paper S-73-1, Report 14, U.S Army Corps of Engineers Waterways Experiment Station, Vicksburg, Mississippi, 1979.

[27] Von Thun, J.L., Rochim, L.H., Scott, G.A and Wilson, J.A., Earthquake ground motions for design and analysis of dams, Earthq. Engineering and Soil Dynamics II, Recent Advance in Ground-Motion Evaluation, Geotec. Special Publication 20, ASCE, New York, 463-481, 1988. 
[28] Nuttli, O.W., The relation of sustained maximum ground acceleration and velocity to earthquake intensity and magnitude, Miscellaneous Paper S-71-1, Report 16, U.S. Army Corps of Engineers, Waterways Experiment Station, Vicksburg, Mississippi, 1979.

[29] Rathje, E.M., Abrahamson, N.A. and Bray J.D., Simplified frequency content estimates of earthquake ground motions, Journal of Geotechnical and Geoenvironmental Engineering, Vol. 124, No. 2, pp. 150-159, 1998.

[30] Ishihara, K., Soil Behaviour in Earthquake Geotechnics, Oxford Engineering Science Series, Oxford University Press, U.K., 1996. 
